\title{
O celular na aula de inglês: relato de experiência.
}

Ana Paula Loureiro ${ }^{1}$

\begin{abstract}
Resumo
O objetivo desse trabalho é apresentar uma proposta de incentivo à participação dos alunos em uma atividade que possibilite a elaboração de quadrinhos via aplicativo para celulares "Comic Striplt!". Os alunos trabalharam em pares, desenvolvendo a comunicação escrita - leitura e produção de textos em inglês - que envolveu a construção de uma narrativa multimodal. A motivação para implantar esse trabalho foi o desejo de usar o celular como uma ferramenta pedagógica em sala de aula. A possibilidade de trabalho em parceria favoreceu a interação e o próprio controle sobre as atividades e seu encaminhamento, o que estimulou a troca colaborativa e a negociação que extrapolaram a relação professora- aluno, engendrando múltiplos diálogos. 0 relato a ser apresentado na comunicação foi desenvolvido com alunos do sexto ano do Ensino Fundamental, em uma escola pública do município do Rio de Janeiro.
\end{abstract}

Palavras-chave: Celular. Interação. Multimodal

\begin{abstract}
The goal of this work is to present a class activity that motivates students to create comic strips in English via a mobile app (application) called "Comic Striplt!". The students worked in pairs, reading and producing texts in English - which involved the construction of a multimodal narrative. The motivation to implement this work was the desire to use the cell phone as a pedagogical tool in the classroom. The possibility of working in pairs favored interaction and stimulated collaboration in class. The report to be presented developed in a public school located in the city of Rio de Janeiro - was carried out in sixth-grade classes of English as a foreign language.
\end{abstract}

Keywords: Cell phone. Interaction. Multimodal narrative.

\section{Introdução}

Santaella (2010) defende que as estruturas digitais híbridas de textos, imagens, áudios e vídeos têm possibilitado a criação de uma lógica pouco explorada anteriormente. Essa lógica - característica da hipermídia - é própria das redes nas quais os meios de produção, de armazenamento, de distribuição e de recepção se fundem em um todo complexo. Neste, parecem sumir as tradicionais bordas comunicativas entre produção, de um lado, e recepção, de outro.

As telas de televisão e do computador nos abrem as portas dos mundos global $e$ local sob a forma de discursos altamente semiotizados. Para Kress (2003), a nova mídia, em

\footnotetext{
${ }^{1}$ Mestre em Linguistica Aplicada e Professora de Inglês do Colégio Pedro II - CPII campus Humaitá II, na cidade do Rio de Janeiro.
}

LínguaTec, Instituto Federal de Educação, Ciência e Tecnologia do Rio Grande do Sul, Bento Gonçalves 
oposição à velha mídia (por exemplo, dos livros), passa a lançar mão também de imagens, sons, música. Ainda segundo Kress (/bia., p. 6-7), a própria escrita está sendo organizada e estruturada pela lógica do visual. As páginas de revistas, e até as de livros contemporâneos, assemelham-se às telas, nas quais a escrita assume papel subsidiário.

É inegável que hoje vivemos em constante exposição a múltiplos discursos midiáticos hipersemiotizados, que temos acesso a uma diversidade de práticas socioculturais e que nos deparamos com uma velocidade intensa de renovação e circulação dos saberes. Tal contexto parece problematizar visões de linguagem, sujeito, mundo social, conhecimento e ensino-aprendizagem tradicionalmente chanceladas em nossas práticas pedagógicas.

Com base nessas ideias, creio poder fazer uma série de questionamentos sobre 0 contexto educacional brasileiro: essa onipresença dos discursos multimodais midiáticos não colocaria em xeque o letramento escolar ainda fundamentado no valor da palavra escrita? Se muitos de nossos alunos, acostumados à infotecnologia, preferem a busca $e$ experimentação à dependência dos adultos, por que continuamos a priorizar um padrão comunicacional centralizado no monólogo professoral? Para uma geração na qual ação, imagens e sons têm significativo apelo, a sala de aula convencional não se tornaria pouco interessante e nada desafiadora?

É meu juízo que, apesar de tantas mudanças e das novas demandas da contemporaneidade, a Educação parece negligenciar esses novos desafios, insistindo em manter-se "fora" de um mundo em permanente mudança. O momento sociohistórico contemporâneo põe em xeque as práticas pedagógicas, sinalizando uma possível dissonância entre o que acontece na escola e no mundo à sua volta. Faz-se necessário, dessa forma, sintonizar o letramento escolar e a dinâmica pedagógica com a realidade do século XXI.

As tecnologias digitais levam-nos a pensar em leitores também produtores de textos híbridos, em diferentes linguagens e recursos digitais. Isso lança luz sobre a premência de criar materiais didáticos que atendam à perspectiva de novos letramentos necessários para dar conta dessa contínua diversificação e complexidade de práticas de linguagem, de outros perfis de leitores e sobre o papel da leitura e da escrita em função das novas tecnologias 
digitais. Esse desafio tem gerado cada vez mais trabalhos nas salas de aula que relacionam objetos semióticos diversos, de modo a estimular o interesse do aluno.

Verifica-se hoje uma presença considerável de celulares no espaço da escola e por meio deste recurso o acesso às redes sociais, à internet e ao aplicativo Whatsapp tem se tornado cada vez mais constante. A internet parece estar nos bolsos e nas mãos de crianças e adolescentes. Dessa maneira, há uma preocupação de como a escola está lidando com os impactos desta realidade nos processos de ensino-aprendizagem.

Não se pode negar que os aparelhos móveis estão cada vez mais presentes em todos os lugares. Por conta disso, a UNESCO (Organização das Nações Unidas para a Educação, a Ciência e a Cultura) publicou um guia digital com recomendações para transformar os celulares em ferramentas da educação. Estas diretrizes descrevem os benefícios específicos da aprendizagem móvel e a necessidade de rever políticas existentes que tratam do uso dos dispositivos móveis em escolas.

Entretanto, o uso desses equipamentos ainda é proibido por lei municipal na cidade do Rio de Janeiro. Na verdade, venho travando uma verdadeira "batalha" com os celulares em minhas aulas. Nos últimos anos, em turmas de Ensino Fundamental e Médio, o cenário parece ser o mesmo em aula: alunos que levam o celular para a escola e estão, a todo momento, tentando usá-lo. Segundo Sibilia (2012), esses estudantes driblam as proibições das autoridades escolares, na tentativa de sobreviver à monotonia e à chatice de permanecerem desconectados por horas nas salas de aula. Em meio a esse ambiente, chego a ficar até mesmo cansada de tanto pedir aos alunos que guardem os aparelhos. Já enfrentei, inclusive, casos de comportamento desrespeito por conta dessa proibição do uso. Em caráter intuitivo, senti a necessidade de me "unir ao inimigo", ou seja, fazer do celular um possível "aliado" pedagógico.

Cardoso (2015), ao pesquisar o uso de tecnologias na formação inicial de professores, indica que para atuar na sociedade em tempos atuais, o professor precisa lançar mão de diferentes recursos tecnológicos e espaços, bem como saber utilizar a tecnologia como ferramenta pedagógica para favorecer, dentre outros aspectos, a colaboração e autonomia através de reflexão sobre sua prática. E de que o mundo mudou muito nas últimas décadas, ninguém há de discordar. Surgem novas formas de ser, de se comportar, de discursar, de se 
relacionar, de se informar, de aprender. Novos tempos, novas tecnologias, novos textos, novas linguagens (ROJO, 2015, p.116).

O objetivo desse relato de experiência é apresentar uma proposta de incentivo à participação dos alunos em uma atividade que possibilite a redação de quadrinhos em inglês via aplicativo para celulares "Comic Strip/t!". Como os alunos estão bastante familiarizados com a leitura de histórias em quadrinhos em língua portuguesa, acreditei que a opção por esse gênero textual - em uma versão digital - poderia ser um facilitador para a realização da atividade. Os alunos trabalharam em pares, desenvolvendo a comunicação escrita leitura e produção de textos em inglês - que envolveu a construção de uma narrativa multimodal. A motivação para implantar esse trabalho foi o desejo de usar o celular como uma ferramenta pedagógica em sala de aula. Supunha que associar o uso do inglês à tarefa realizada no celular poderia provocar maior envolvimento do alunado na aula. Na verdade, creio que todo professor se pergunta sobre como imprimir sentido ao ensino escolar, unindo gramática e produção textual aos interesses dos alunos. 0 relato a ser apresentado foi desenvolvido com alunos do turno da manhã, em três turmas no sexto ano do Ensino Fundamental, em uma escola pública do município do Rio de Janeiro.

\section{Organização da tarefa: construção do "my photocomics"}

Seguindo a determinação da lei número 5222, de 11 de abril de 2008, a escola proíbe 0 uso de telefones celulares nas salas de aula. Por esse motivo, apresentei à direção do colégio minha intenção de trabalhar com celulares em aula. Em seguida, redigi uma circular aos responsáveis, explicando o uso de celulares numa aula de inglês, em data previamente agendada, com objetivo estritamente pedagógico. A fim de evitar um possível constrangimento, ressaltei que qualquer impedimento de levar o telefone para a escola não traria prejuízo ao estudante, uma vez que o trabalho poderia ser feito em dupla, com um colega que tivesse o dispositivo móvel. Optei por não atribuir nenhuma nota, porque meu desejo era tratar esse momento como mais uma atividade de sala de aula. O que considerei, essencialmente, foi a vivência da experiência com o celular em aula e as reflexões que os alunos fizeram sobre isso. 
Os alunos do sexto ano que participaram da dinâmica com celulares em aula têm idades entre 10 e 12 anos e, em sua maioria, iniciaram o estudo do inglês nessa série. Alguns deles, em cada turma, frequentam aulas de inglês em cursos de idiomas. Por essa razão, as turmas apresentam integrantes em níveis de competências diferentes. As turmas têm em torno de 30 alunos. Em média, em cada uma delas, 24 a 25 alunos afirmaram possuir telefones celulares do tipo "smartphones", com acesso à internet.

Preparei, no programa Impress, do LibreOffice, a apresentação da tarefa, de forma bem clara e objetiva. Cada dupla deveria escolher o mínimo de seis e o máximo de 12 fotos de eventos com familiares e/ou com amigos. Cada foto corresponderia a um quadrinho. Os personagens das fotos seriam apresentados em frases em inglês por meio de balões de fala ou de legendas em cada quadrinho. Em dois tempos de aula (noventa minutos), mostrei às turmas os slides e uma amostra de "photocomics"2 (Cf. Anexo 1), que eu mesma criei, ao testar o aplicativo em meu celular. Percebi que, enquanto eu mostrava meu trabalho, vários alunos já estavam baixando o aplicativo. Após a apresentação, pedi que eles se organizassem em pares. Cada dupla deveria baixar em casa o aplicativo gratuito chamado “Comic Striplt!", disponível no Google Play Store (Cf. Anexo 2). Aproveitei para esclarecer que esse aplicativo não era compatível com o sistema operacional iOS3.

É importante destacar que a tarefa proposta relaciona-se com a temática desenvolvida no livro didático de inglês do sexto ano do Ensino Fundamental II, referente ao Programa Nacional do Livro Didático (PNLD), privilegiando o conteúdo programático desse material que orienta a dinâmica em sala de aula. Nas primeiras unidades do livro didático, os alunos aprendem a "falar de si" e "do outro", fornecendo informações, tais como nome, idade, origem, ocupação e grau de parentesco familiar. Como nos exemplos dos textos lidos em aula, cada dupla deveria usar fotos de eventos com familiares e/ou amigos, apresentando em inglês quem está na foto, onde a(s) pessoa(s) está / estão na hora da foto e qualquer outra informação que desejassem.

Sem a minha participação direta, as duplas logo se engajaram na discussão da tarefa, discutindo suas ideias, ao mesmo tempo em que combinavam as fotos e imagens a serem utilizadas. Combinei com as turmas, ao final dessa aula, que sete dias depois, em nosso

\footnotetext{
2 Photocomics são quadrinhos em inglês que usam fotos como ilustrações

3 iOS é um sistema operacional móvel da Apple Inc. desenvolvido originalmente para o iPhone
} 
próximo encontro de dois tempos, faríamos a redação das legendas das fotos e balões de fala a serem postados nos photocomics. Orientei aos alunos a selecionarem no mínimo seis e no máximo doze fotos. Reforcei que o objetivo do photocomics era apresentar familiares e amigos. Cabe lembrar que essa construção textual envolveria o uso de vocabulário e produção das estruturas aprendidas em sala de aula, orientados pelo livro didático.

No encontro previamente combinado, distribuí os storyboards4 (Cf. Anexo 3) às duplas, retomando o objetivo da tarefa. Cada quadrinho corresponderia a uma foto, acompanhado por sua respectiva legenda e/ou balão de fala em inglês, contendo, pelo menos, uma sentença em inglês. Observei que, igualmente nas três turmas, alguns poucos alunos ainda estavam sem duplas, enquanto outros não tinham escolhido suas fotos, como havia sido combinado. No entanto, acredito poder dizer que a maioria parecia comprometida com o trabalho, usando os celulares para checarem as fotos armazenadas e até mesmo fazendo pesquisa de informações na internet. Ao invés de me perguntarem dúvidas de vocabulário, percebi que preferiam usar a internet para buscar as respostas. Até me arrisco a dizer que esse comportamento possa ser um sinal de maior autonomia desses alunos. Circulei bastante pelas salas de aula, atendendo às dúvidas e às solicitações dos alunos. Ao me aproximar das duplas, observava que os alunos que tinham mais facilidade empenhavam-se em auxiliar aqueles com dificuldades. Ao usarem os celulares ao mesmo tempo em que encaminhavam a tarefa, conversando em português sobre seus textos e escrevendo em inglês as legendas e/ ou balões de fala no storyboard, os alunos pareciam mais engajados com o próprio trabalho colaborativo - o que aponta para uma possibilidade de maior participação e aproveitamento desses adolescentes em aula.

Essa primeira versão dos textos em inglês no storyboard foi entregue ao final da aula. Combinamos que, sete dias depois, em nosso próximo encontro de dois tempos, faríamos a redação final dos photocomics nos celulares, usando o aplicativo "Comic Strip/t!". Aproveitei para lembrá-los da importância de levar os celulares com as fotos armazenadas. Corrigi os erros de todos os storyboards, verificando o uso de vocabulário pertinente e a correção das estruturas gramaticais. A correção de possíveis erros gramaticais e lexicais oferece aos alunos uma nova oportunidade de aprendizagem. A

\footnotetext{
4 Storyboard é um guia visual que narra as principais cenas de qualquer mídia audiovisual
} 
reescritura do texto a partir de feedback do professor ajuda aos alunos a refletirem sobre seus erros e a aprenderem com eles.

No dia da redação final, os storyboards com as devidas correções foram devolvidos para servirem como legendas e/ou balões de fala dos quadrinhos nos photocomics. Para facilitar o trabalho, entreguei o roteiro (Cf. Anexo 4) com orientações da tarefa e um tutorial (Cf. Anexo 5) para ensiná-los a usar o aplicativo- que é bem simples. Pude observar que muitos já até sabiam como usá-lo.

Em uma proposta de incentivo à autonomia do aluno, houve a preocupação com a elaboração de tarefa que privilegiasse a interação colaborativa entre os aprendizes e a redação de orientações claras e objetivas. Destaco que, durante as aulas de elaboração das tarefas, o controle do trabalho interacional e do que é realizado estava nas mãos dos próprios alunos. A interação parecia ser encaminhada de forma mais simétrica e cooperativa.

Apesar de todos os combinados feitos, ainda havia duplas que deixaram para escolher as fotos no momento da criação do photocomics, recorrendo às outras imagens armazenadas em suas galerias de fotos nos celulares. A partir do momento em que cabe aos alunos se responsabilizarem pelo controle das tarefas, eles parecem agir com maior autonomia para tomar decisões e expressar suas ideias.

Por problemas de relacionamento, alguns alunos optaram por trabalhar sozinhos. Em contrapartida, por conta de alguns faltosos, foi preciso inserir alunos em duplas já formadas, pois eles se recusavam a trabalhar sozinhos. Houve até duas duplas, em turmas diferentes, que já tinham feito todo o photocomics em casa. Para minha surpresa, uma aluna, que ficou tão entusiasmada com o aplicativo, elaborou sozinha em casa, um photocomics com legendas em português para montar um álbum de fotos de uma viagem da sua família. Como já observado, os alunos que tinham mais facilidade, tanto nas habilidades de lidar com aplicativos quanto na língua estrangeira, tinham prazer em ajudar àqueles que ainda apresentavam dúvidas. Uma vez que a professora não centraliza a comunicação nem controla a interação, os alunos podem negociar mais livremente o "papel de par mais competente" em sala de aula, enquanto desenvolvem ações mais cooperativas. A meu ver, o ritmo do trabalho foi variado nas turmas. Em pouco tempo, algumas duplas realizavam a tarefa com certa tranquilidade, enquanto outras pareciam demandar que eu lhes dissesse 0 
que fazer. Solicitavam minha ajuda, pedindo que eu lesse e avaliasse o photocomics em construção. Apesar de haver mais espaço para participação e colaboração, ainda havia alunos agindo com certa dependência.

Afinal de contas, ao abrir espaço para a negociação e para trocas intersubjetivas mais intensas, é possível perceber outros tipos de interações, que parecem pôr em evidência uma maior dependência do aluno à voz "avaliadora" da professora a apontar o que é certo ou errado. E aqui cabe refletir sobre o que esses alunos fazem com a possibilidade de usufruir da maior liberdade e autonomia que lhes é concedida. Ao invés de construir um espaço de maior responsabilidade e engajamento, vários deles pareciam fazer o mínimo possível, livrando-se logo da tarefa e dependendo da voz professoral ou da ação de um “par mais compentente" para lhes apontar o que fazer e como fazer. Ou talvez, melhor dizendo, evidenciou-se, durante o trabalho nas três turmas, um confronto de ações - maior dependência x maior autonomia - que até poderia sugerir uma possibilidade de revisão das práticas interacionais recorrentes na sala de aula.

Como fechamento do trabalho, o photocomics precisava ser compartilhado. Como a maioria não possuía e-mail, forneci aos alunos meu número de "Whatsapp" para compartilhamento dos arquivos digitais. Atribuo essa preferência pelo uso do software para troca de mensagens à experiência de vida que esses alunos têm fora da sala de aula, dentro do cenário da contemporaneidade. Por problema de falta de conexão à internet, houve casos de duplas que não conseguiram fazer o envio do texto ao final da aula. Ficou acertado, então, que o fizessem como tarefa de casa. É nesse momento que percebemos os entraves e dificuldades que precisamos enfrentar na esfera pública. A escola não dispõe de rede de $W I-F I$ e nem todos os alunos possuem conexão à internet disponível para uso em seus aparelhos de celular. Apesar disso, do total de 35 photocomics, 29 - cerca de 83\% foram enviados. Cada arquivo recebido foi baixado e salvo em formato PDF como preparação para a mostra de trabalhos, previamente combinada por ocasião da apresentação da proposta da tarefa.

Por conta da semana de provas, só foi possível mostrar os photocomics às turmas em dois tempos de aula, às vésperas do recesso escolar de julho. Essa mostra se realizou nas salas de aula das turmas envolvidas. Era o momento de disponibilizar para todos uma 
versão final do trabalho desenvolvido. Os alunos reagiram positivamente, aplaudindo os photocomics dos colegas.

\section{Reflexões a partir dos questionários de avaliação da atividade}

Durante as aulas, eu elaborava o diário de campo, anotando aquilo que julgava pertinente. Com o intuito de incorporar a percepção dos alunos a respeito do uso do celular em tarefa de sala de aula, recorri ao questionário, aplicado ao final da mostra dos photocomics. Cada dupla recebeu um único questionário. A partir da discussão em pares, eles construíram sua própria opinião, registrada nas respostas.

O questionário (Cf. Anexo 6) é composto por sete questões. Para garantir a preservação da identidade de cada estudante, pedi que não os assinassem. Trinta e oito questionários foram respondidos. Uma das questões abordadas referia-se à proibição do uso do celular em aula. As regras da instituição proíbem o uso desse tipo de material. Mesmo assim, os estudantes insistem em contrariar essas regras, pois, na verdade, o que eles desejam é a liberdade de utilizar o aparelho como bem queiram. Ao burlarem a proibição, parecem usar seus dispositivos móveis na tentativa de sobreviver a longas horas em que permanecem desconectados nas salas de aula. Se os alunos desejam tanto usar seus aparelhos em aula, eles mesmos deveriam apresentar possíveis formas de viabilizar o uso desse equipamento em aula. 


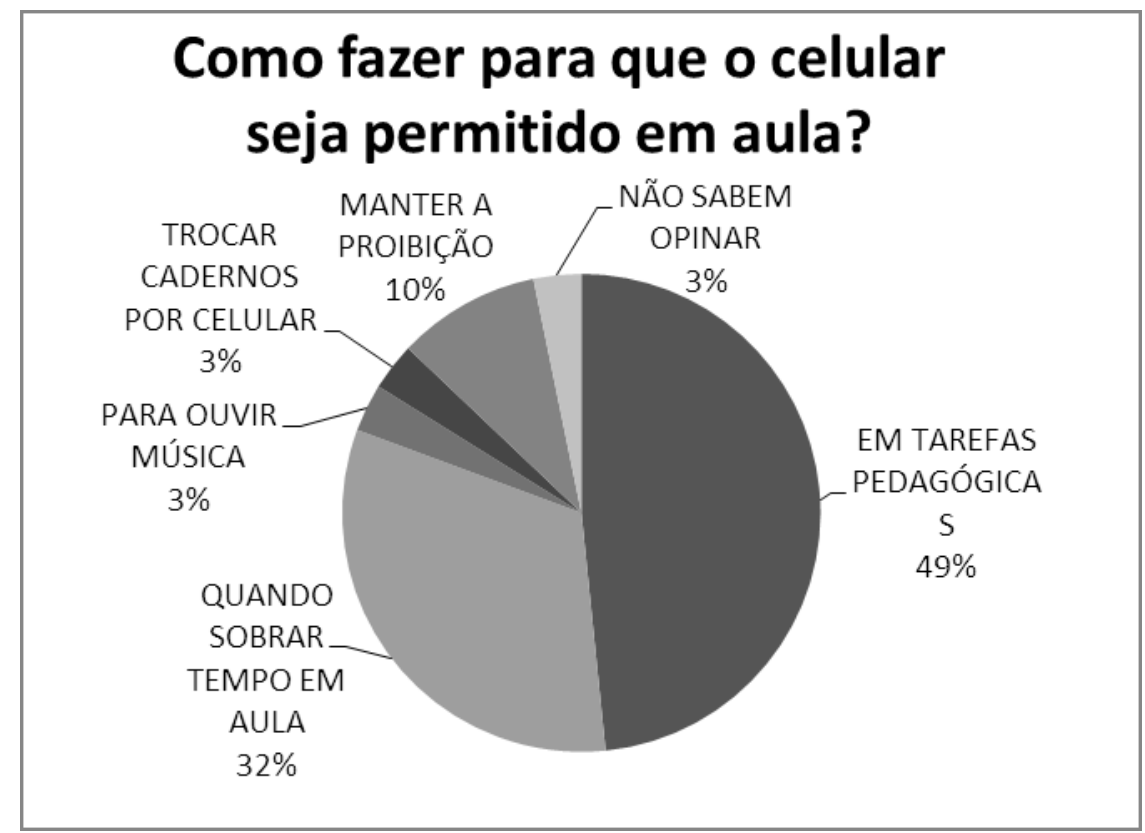

Figura 1: Sugestão dos alunos sobre possíveis usos do celular em aula. Fonte: A autora.

A partir do gráfico anterior, percebemos que para $49 \%$ dos alunos esse problema seria resolvido com o maior estímulo ao uso da ferramenta em atividades pedagógicas. Isso parece sinalizar que boa parte dos alunos entende que o celular tem potencial para servir como instrumento para aprendizagem.

Em outro item, a seguir, investiguei a importância que o celular poderia ter na vida dos adolescentes. Fica evidente que para a maioria o dispositivo móvel ainda parece ser visto somente como um recurso tecnológico de comunicação e entretenimento. Isso me faz pensar que o celular está longe de ser utilizado como um aliado à aprendizagem para esses estudantes. A liberação do uso desse equipamento passa, acima de tudo, por um longo processo de ressignificação da visão que esses adolescentes possuem do celular. A meu ver, cabe à escola e aos educadores iniciar esse caminho de desconstrução desses sentidos já arraigados que eles parecem ter em relação ao próprio uso do celular. 


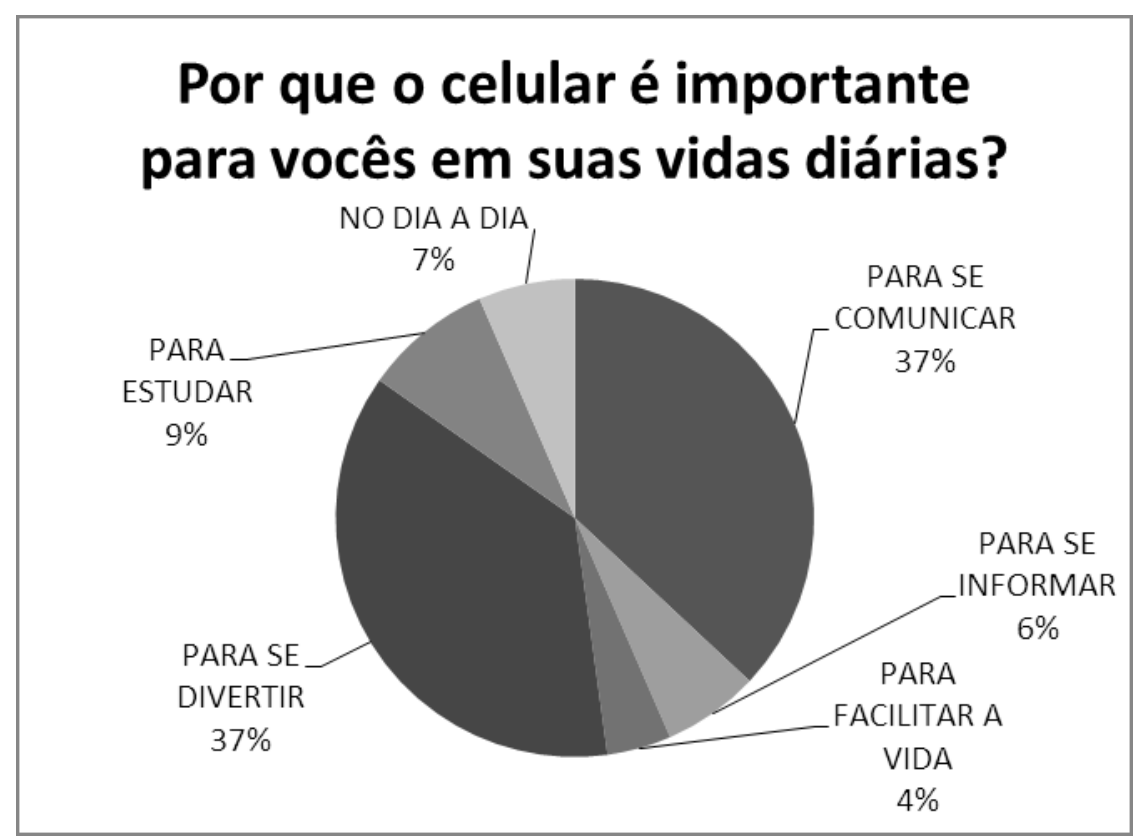

Figura 2: Alunos apontam a importância do celular em sua vida diária. Fonte: A autora.

Quando indagados “Vocês já usaram o celular em alguma tarefa autorizado pelo professor em aula?", 78\% afirmaram que tinham usado os celulares em aula pela primeira vez com a experiência do photocomics.

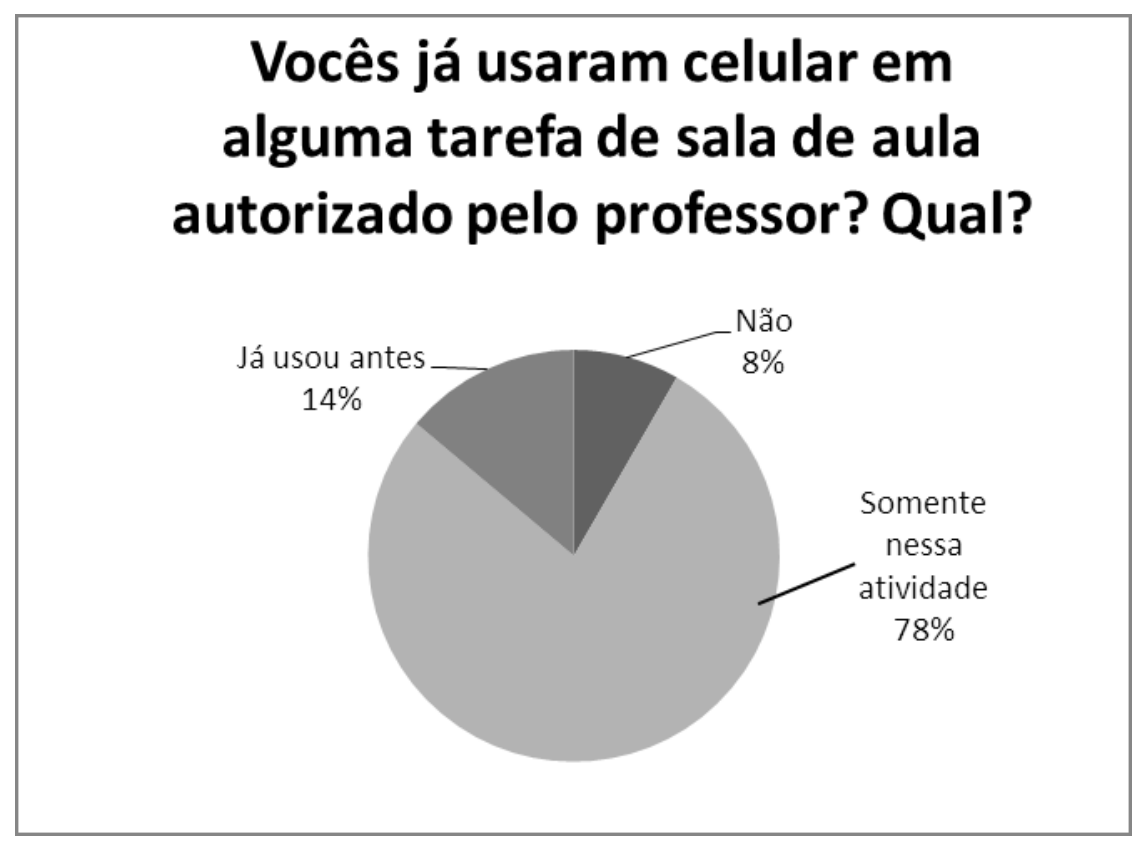

Figura 3: Alunos apontam o uso do celular em atividades pedagógicas anteriores. Fonte: A autora. 
A possível carência desse tipo de trabalho em aula parece manter a escola desvinculada do contexto social contemporâneo. $\mathrm{O}$ uso do celular em sala de aula demanda um exercício de reflexão sobre a própria prática pedagógica. Cumprir as regras passivamente acabará por reforçar um paradigma que sinaliza aos alunos que o celular não "combina" com a sala de aula. Com planejamento cuidadoso, parece viável a execução de tarefas pedagógicas que façam do celular uma ferramenta a favor da aprendizagem.

Em outra questão, observei que a participação nessa dinâmica com dispositivos móveis na aula de inglês agradou e interessou a $78 \%$ dos alunos. Para uma geração que tem o celular "à mão" no seu dia-a-dia, a chance de usá-lo para trabalhar em aula parece aproximar a prática pedagógica do que acontece fora da escola.

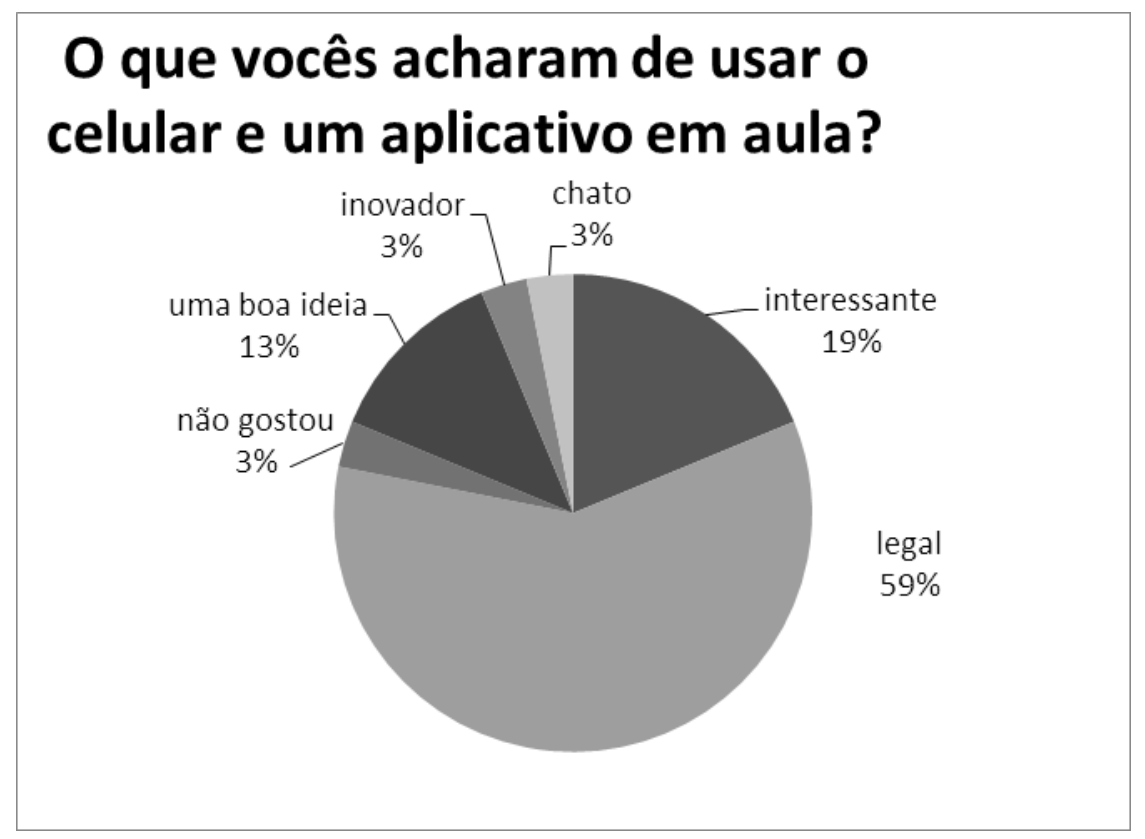

Figura 4: alunos apontam suas impressões sobre o uso do celular e do aplicativo em aula. Fonte: A autora.

Outra pergunta investigou sobre a dificuldade em usar o aplicativo "Comic Strip/t!". Constatei que $44 \%$ dos alunos afirmaram conseguir manusear o aplicativo com facilidade. No meu entender, esses adolescentes já se consideram acostumados a lidar com essa ferramenta, como aponta o gráfico a seguir: 


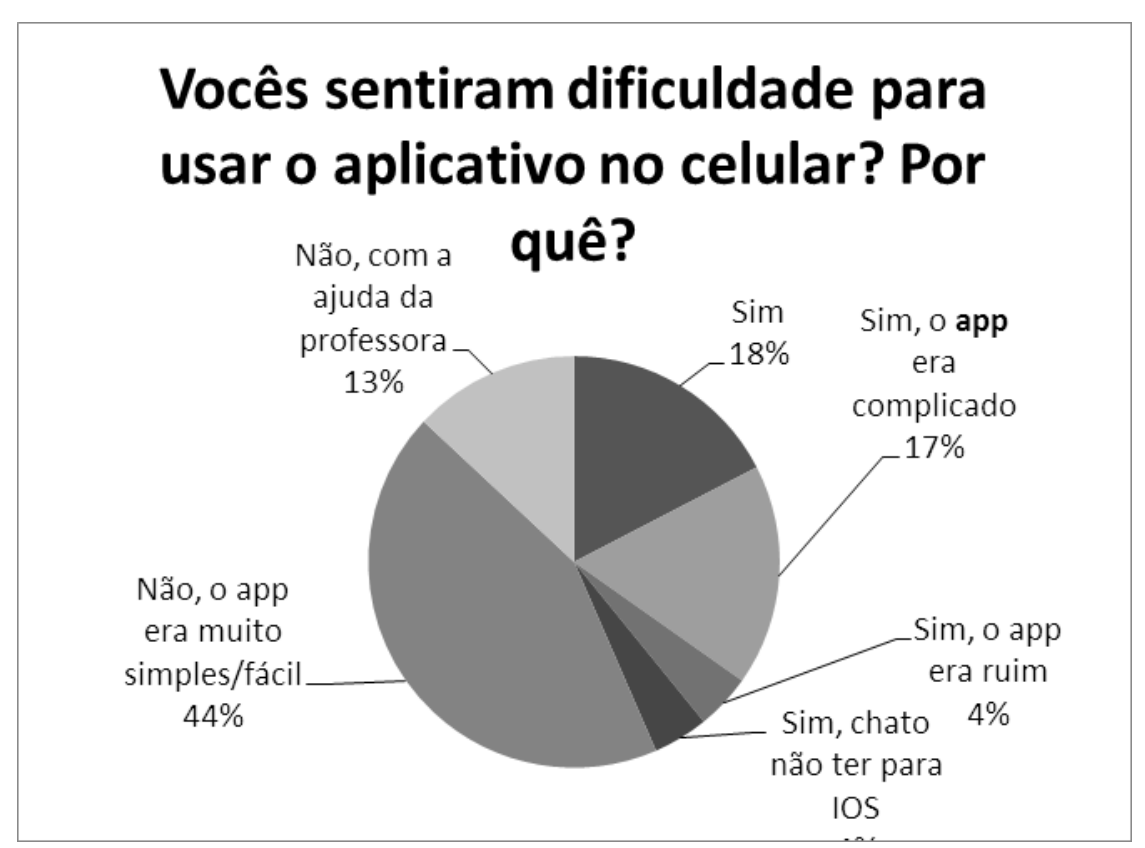

Figura 5: Alunos indicam possíveis dificuldades para usar o aplicativo sugerido.

Fonte: A autora.

É importante levar em conta que muitos dos interesses e atividades de jovens $e$ adolescentes fora da escola são geralmente mediados pelas novas tecnologias. Acostumados à linguagem multimodal e fragmentada dos discursos midiáticos, os estudantes sentem-se, portanto, "mais à vontade" ao interagir com recursos tecnológicos. Não é por acaso que cerca de $41 \%$ gostariam que o celular fosse usado com mais frequência em aula, como se pode observar no gráfico abaixo. Considerando-se que esses alunos estão a todo tempo tentando usar seus celulares em aula, parece-me um pouco estranho que a maioria não queira usá-lo com mais frequência. Entretanto, arrisco-me a dizer que os sentidos já disponíveis na cultura e que são atribuídos ao uso do aparelho móvel, especialmente voltado para comunicação e entretenimento, não parecem combinar com novos sentidos conferidos às práticas pedagógicas. 


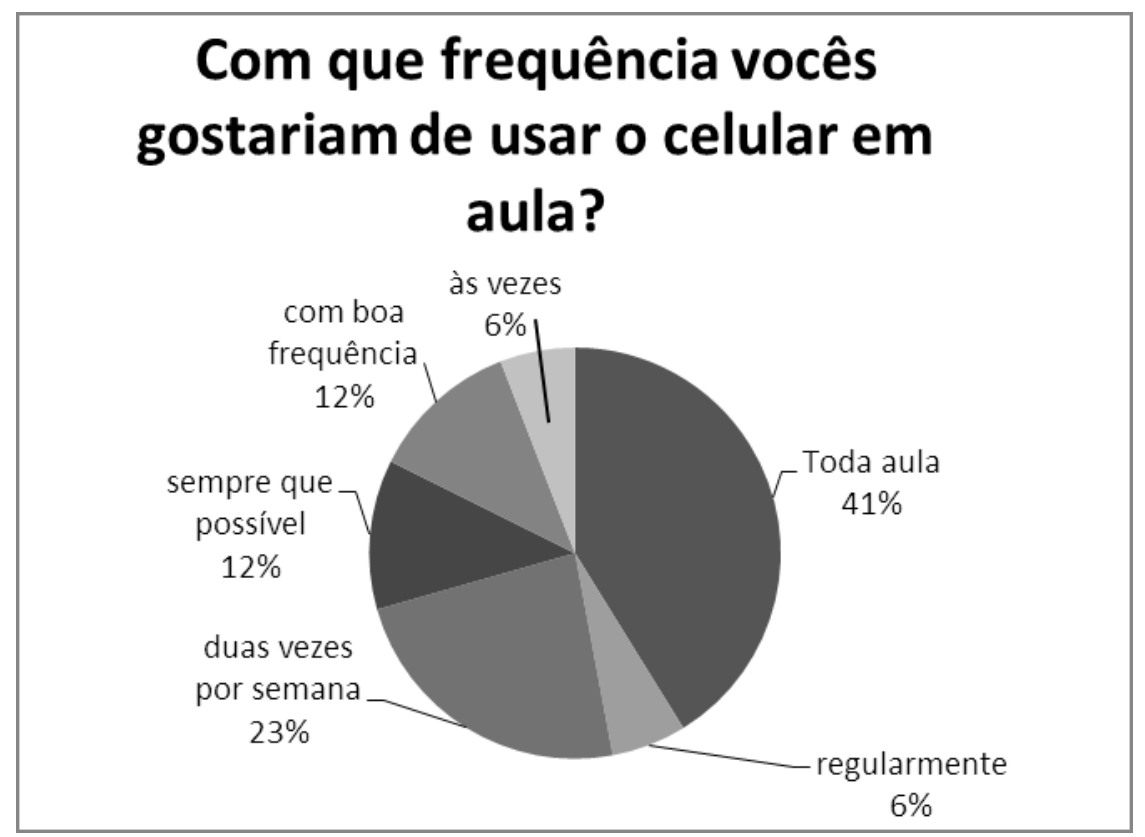

Figura 6: Alunos sugerem com que frequência gostariam de usar o celular em aula. Fonte: A autora.

Quando perguntados “Q̣ue atividades vocês sugerem para serem feitas no celular em aula?", o alunado não hesita, sugerindo possíveis formas proveitosas de inserção do celular no trabalho pedagógico, tais como pesquisa de informações, edição de vídeos e/ou fotos e trabalhos com músicas. É desse modo, portanto, que alunos parecem contribuir para o processo de ressignificação do uso de celular em aula. Em contrapartida, creio que a maioria dos professores ainda prefere ratificar a proibição do uso dos aparelhos. Essa breve trajetória me levou também a refletir sobre o que meus colegas professores pensam sobre o uso do celular como recurso pedagógico. De fato, venho me questionando muito a respeito dos desafios e possibilidades de como utilizar o potencial de dispositivos móveis no processo de construção de conhecimento em sala de aula. 


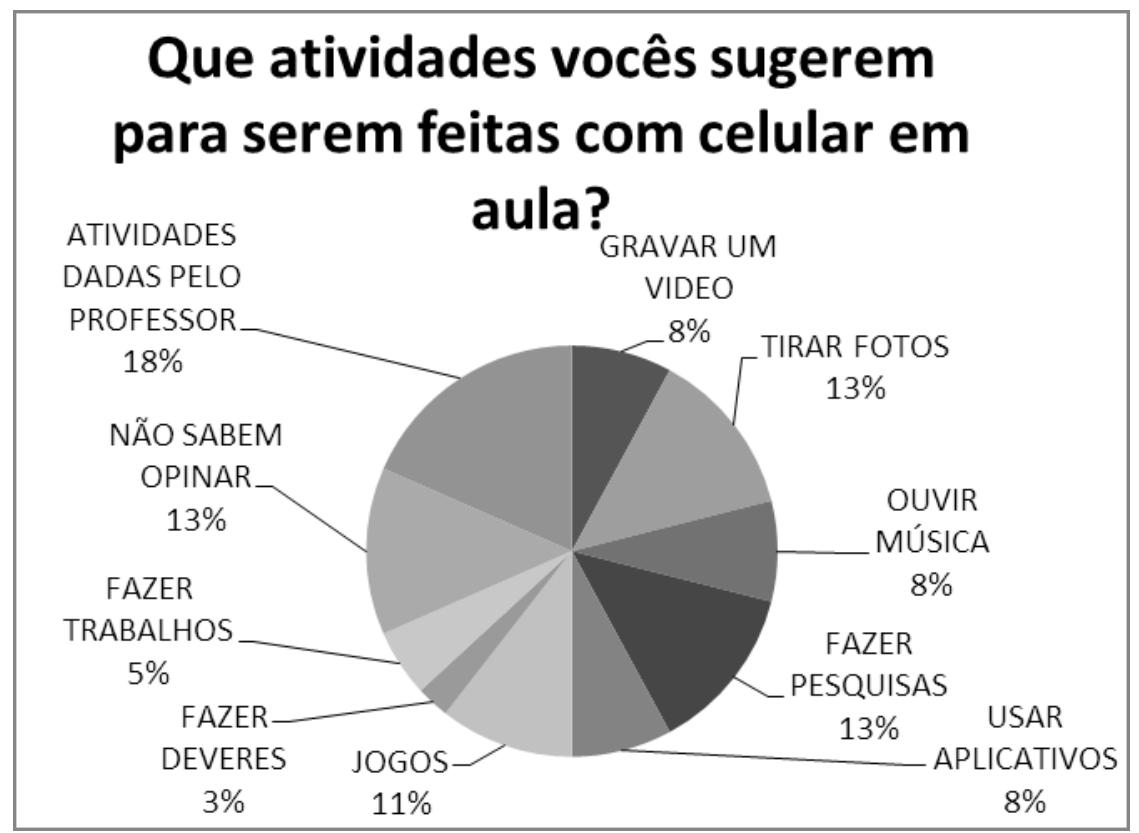

Figura 7: Alunos sugerem possíveis maneiras de usar o celular em aula. Fonte: As autoras.

\section{Considerações finais}

O objetivo de apresentar uma proposta de incentivo à participação dos alunos em uma atividade que possibilitasse a redação de pequenos textos em inglês via aplicativo para celulares foi alcançado. A elaboração dos photocomics envolveu as turmas, garantindo uma possível revisão do conteúdo visto em aula, ao mesmo tempo que desenvolvia a capacidade criativa e integrava a realidade - fotos dos estudantes, amigos e/ou familiares - ao uso da língua estrangeira, para dar sentido àquilo que foi estudado. As reações dos alunos participantes sinalizaram que a experiência de usar o celular como uma ferramenta pedagógica em sala de aula pode ser positiva e motivadora. Essa motivação, acredito, propiciou uma experiência de colaboração e crescimento mútuos. 0 trabalho foi realizado com, relativamente, poucos recursos. Apenas o aparelho móvel e o aplicativo gratuito, associados a um roteiro e a um tutorial criados pela professora, ajudaram a viabilizar a tarefa.

Cabe também destacar que a possibilidade de trabalho em parceria favoreceu a rearticulação das regras que regem a interação, a comunicação em aula e o próprio controle sobre o encaminhamento da atividade, estimulando a troca e a negociação que extrapolaram a relação professora-aluno, engendrando múltiplos diálogos. A utilização das tecnologias em sala de aula não demanda somente a presença de ferramentas, mas 
também a devida orientação pedagógica. Os professores devem, portanto, se preparar para aprender a lidar com os recursos tecnológicos básicos, planejando formas de usá-los em aula (COSCARELLI, 2011). O exercício de reflexão sobre a prática docente demanda a observação constante de nossa própria sala de aula. 0 que me parece fundamental é entender que cabe a nós mesmos a responsabilidade de propor novos sentidos sobre a realidade e sobre nós mesmos nas práticas pedagógicas nas quais nos engajamos.

Afinal de contas, o professor que não interroga sobre si próprio e ignora as transformações no mundo que o rodeia não se transforma e tende a se estagnar, afastandose da dinâmica contemporânea marcada por instabilidade, mudança constante e flexibilidade. É o processo de experimentação, reflexão e diálogo que pode ajudar o docente e a escola a repensarem e recriarem os saberes escolares, o currículo e a própria pedagogia, de forma que escola e mundo social se aproximem.

\section{Referências}

CARDOSO, A. C. S. Formação inicial de professores de inglês para o uso das tecnologias digitais: uma pesquisa-ação no contexto do estágio supervisionado. Tese de doutorado, Programa Interdisciplinar de Pós-Graduação em Linguística Aplicada, Faculdade de Letras, Universidade Federal do Rio de Janeiro, 2015.

COSCARELLI, C.V; RIBEIRO, A.(orgs.). Letramento digital: aspectos sociais e possibilidades pedagógicas. Belo Horizonte, MG: Ceale; Autêntica, 2011.

KRESS, G. Literacy in the New Media Age. Londres: Routledge, 2003.

ROJO, R.; BARBOSA, J. P. Hipermodernidade, multiletramentos e gêneros discursivos. São Paulo: Parábola Editorial, 2015.

SANTAELLA, L. A ecologia pluralista da comunicação: conectividade, mobilidade, ubiquidade. São Paulo, SP: Paulus, 2010.

SIBILIA, P. Redes ou paredes: a escola em tempos de dispersão. Trad. Vera Ribeiro. Rio de Janeiro, RJ: Contraponto, 2012.

UNESCO. Policy guidelines for mobile learning. United Nations Educational, Scientific and Cultural Organization. 2013.

Disponível em: <http://unesdoc.unesco.org/images/0021/002196/21641E.pdf.>.

Acesso em: 29 de agosto 2017.

Data de submissão: 29/07/2019. Data de aprovação:22/10/2019. 


\section{ANEXOS}

Anexo 1
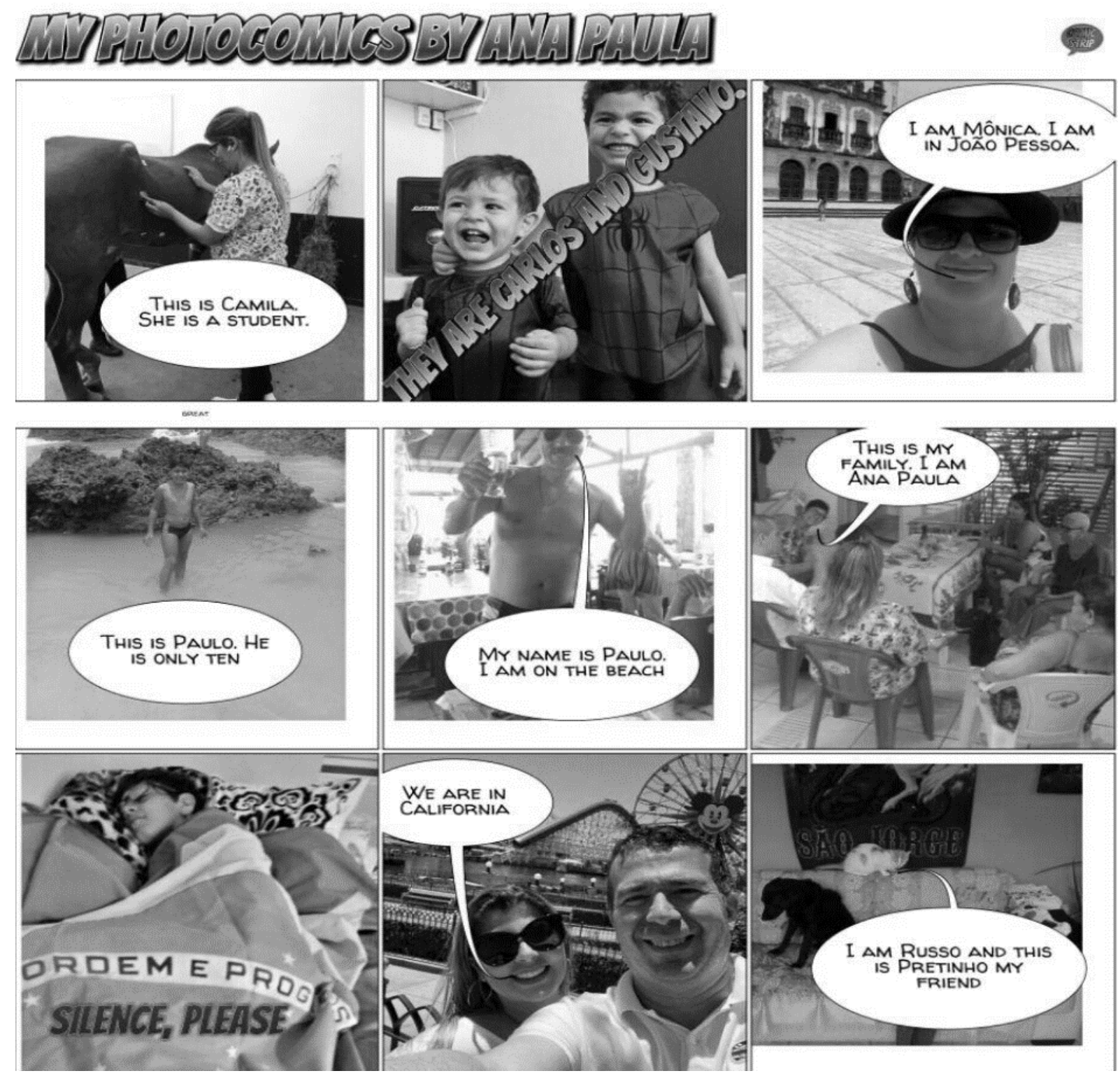

Amostra de photocomics criada para apresentação aos alunos 
Anexo 2

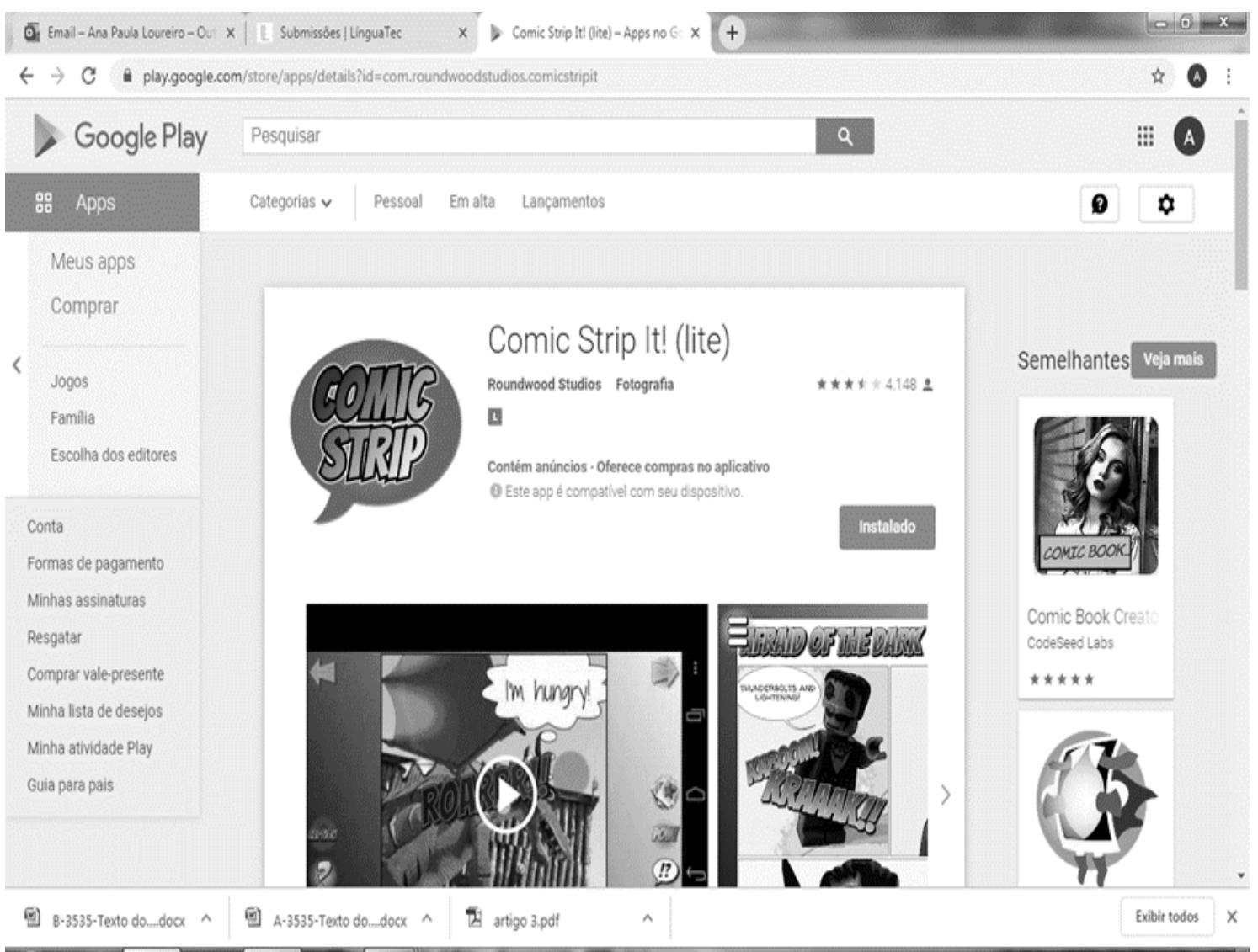

(4) $e$ a

Captura de tela do aplicativo para download

LínguaTec, Instituto Federal de Educação, Ciência e Tecnologia do Rio Grande do Sul, Bento Gonçalves v. 4 , n. 2, p. 186-207, nov. 2019. 


\section{Anexo 3}

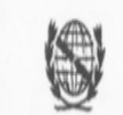

STORYBOARD: Desenhe, de forma simples, a cena ou foto que vocés irăo fotografar sobre o trabalho aquela imagem nas linhas abaixo do quadro:

e escrevam 0 texto referente

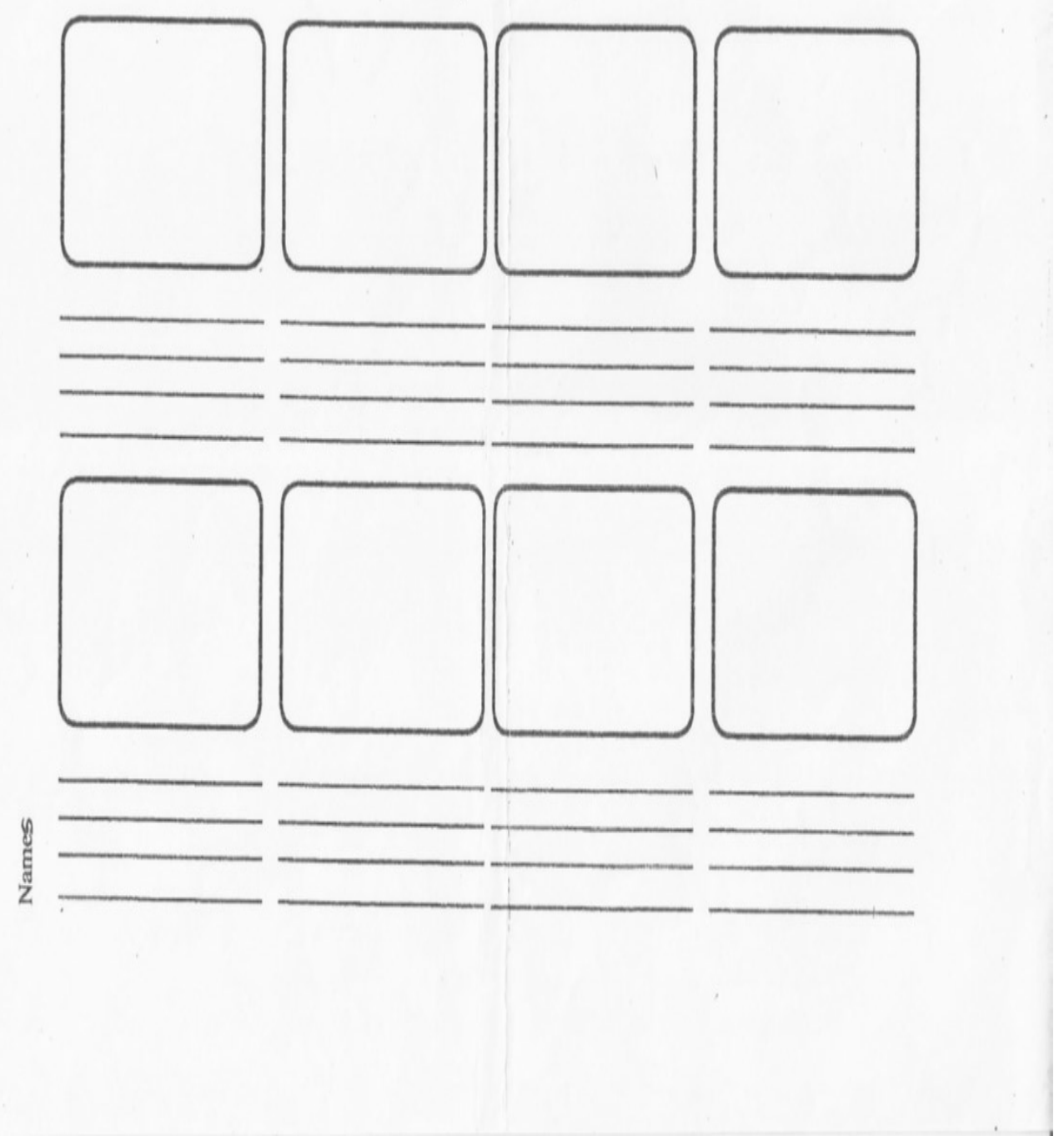

Storyboard usado em aula 


\section{Anexo 4 \\ Roteiro do Photocomics}

\section{PHOTOCOMICS}

Cada dupla fará um PHOTOCOMICS- uma história em quadrinhos a partir de fotos.

A tarefa será realizada no aplicativo gratuito chamado ComicStripit!, que deverá ser baixado em casa.

Escolham de 06 (mínimo) a 12 (máximo) fotos, sobre eventos com familiares e/ou amigos e colegas de escola.

Essas fotos devem ser tiradas fora do espaço escolar, preferencialmente.

Cada foto será um quadrinho de sua história.

Sua professora mostrará em aula um sample para ilustrar e facilitar o trabalho.

Para cada foto vocês farão UMA LEGENDA ou BALÃO DE FALA incluindo frases EM INGLÊS com as seguintes informações:

- Dizer de quem é a foto

- Apresentar a(s) pessoa (s) na foto

- Acrescentar alguma informação relevante como, por exemplo, profissão, etc

Em aula previamente agendada: cada dupla redige numa ficha de papel pequenos textos que servirão de legendas e/ ou balões de fala das fotos tiradas pelas duplas. Esses textos serão corrigidos pela professora.

Em outra data marcada: as duplas levam os celulares com o aplicativo baixado e as fotos digitais armazenadas. Os estudantes usarão suas legendas já redigidas / corrigidas e as fotos tiradas para construírem seus "photocomics". Ao final da tarefa, as duplas deverão compartilhar suas histórias com a professora por email.

Observação: essa tarefa não valerá nota. Cada dupla deve compartilhar um aparelho de celular no qual o trabalho será feito. 


\section{Anexo 5}

Tutorial para usar o aplicativo “Comic Strip It!"

1.Para celulares android SOMENTE: baixar o aplicativo via PLAY STORE

2. Para abrir o aplicativo, basta clicar no ícone "Comic Strip It!" que aparece na tela do celular

3. Clicar na barra de ferramentas lateral à esquerda no símbolo $\equiv$ e escolher "definir faixa título".

4. Clicar no símbolo para escolher uma foto armazenada em sua galeria no

celular. Em seguida, clicar no símbolo

na lateral direita.

5. Você pode escolher inserir um balão de fala (ver símbolo de balão de fala na barra da lateral direita) ou selecionar o símbolo POW! para inserir uma legenda na foto.

6. Ao escolher um balão de fala, você pode selecionar a forma, cor e tipo de letra.

Depois basta clicar em

. Você pode controlar o tamanho do balão ou a direção da parte pontiaguda do balão, apenas tocando na tela e movendo o balão colorido que surgir na imagem. Esse procedimento também vale para escolha de legendas no símbolo POW!

7. Para acrescentar novo quadrinho, basta clicar em NEW FRAME.

Obs: você pode andar para frente ou para trás nos seus quadrinhos, clicando nas setas (à direita e à esquerda) que estão no topo da tela. Se desejar excluir alguma

coisa, clique no na lateral à esquerda

8. Ao finalizar sua photocomics, clicar no símbolo $\equiv$ na barra lateral à esquerda, e escolher SALVAR STORYBOARD. Nomear usando "My photocomics by (nomes da dupla de alunos) e dar $O K$.

9. Para visualizar seu photocomics, clicar no símbolo da

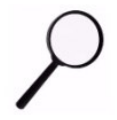

10. Na barra lateral à direita. Em seguida, clicar no símbolo $\equiv$ e SALVAR a história nomeando "My photocomics by (nomes da dupla de alunos) e dar OK.

11. Acesse a história salva na Galeria do seu celular. Você pode editar essa imagem, se desejar. Em seguida, envie para sua professora. Clicar em $M$ (gmail) para o seguinte endereço eletrônico: analou2013@gmail.com 


\section{Anexo 6}

Questionário de avaliação do uso do celular em aula

10 uso do celular é proibido em sala de aula, porque acreditam que ele vai tirar a atenção dos alunos. Como podemos resolver esse problema para que o celular possa ser permitido em aula?

2 Por que o celular é importante para vocês em suas vidas diárias?

3 Vocês já usaram celular em alguma tarefa de sala de aula autorizado pelo professor? Q̨ual?

40 que vocês acharam de usar o celular e um aplicativo em aula?

5 Vocês sentiram dificuldade para usar o aplicativo no celular? Por quê?

6 Com que frequência vocês gostariam de usar o celular em aula?

7 Q̨ue atividades vocês sugerem para serem feitas com celular em aula? 